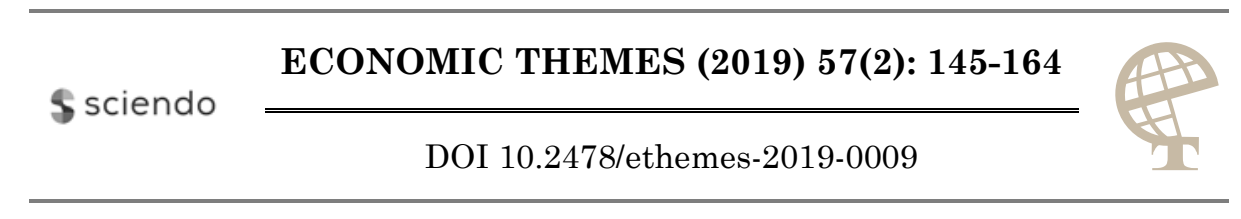

\title{
COMPARATIVE ANALYSIS OF RETIREMENT BENEFITS IN PRIVATE PENSION FUNDS AND PUBLIC PENSION SYSTEM
}

\author{
Stevan Luković \\ University of Kragujevac, Faculty of Economics, Republic of Serbia \\ 凶slukovic@kg.ac.rs \\ Srđan Marinković \\ University of Niš, Faculty of Economics, Republic of Serbia \\ $\bowtie$ srdjan.marinkovic@eknfak.ni.ac.rs
}

UDC

368.914

Original scientific paper

Received: 14.05.2019 Accepted: 19.06.2019

\begin{abstract}
This paper identifies the conditions under which the private pension funds generate superior retirement outcomes compared to public pension system. The research objective is to determine the probability of success of the selected investment strategies in achieving the public pension system replacement rate, and the probability of the realization of extremely unfavourable outcomes. The methodology used in this paper includes the comparative analysis of simulated financial results of the four selected investment strategies implemented in the private pension fund model and the defined retirement benefits generated within the public pension system. For the simulation of the financial results at retirement, Monte Carlo simulation technique has been used. The authors have found that the success rate of the private pension fund in achieving superior financial results in comparison to public pension system is high, but only for the contribution rates higher than $10 \%$. At low contributions rates, the extremely aggressive strategy is the only one that generates moderate success rate. Also, the probability of realization of extremely unfavourable financial results is lowest for the conservative strategy, which suggests that for the relatively high levels of the contribution rate, it is the most appropriate option for the pension fund members.
\end{abstract}

Keywords: pension funds, public pension system, retirement benefits, investment strategy, Monte Carlo simulation

JEL classification: G11, H55, J26 


\section{Introduction}

Considering the growing importance of private pension funds in a number of countries, one of the most interesting research topics in the area of pension insurance is the capability of private sector pension funds to generate satisfactory retirement benefits for members in the long run. Hence, it is useful to perform a comparative analysis of the retirement benefits generated by public pension systems and private sector pension funds. The public pension system may include an unfunded PAYG pension system, but also the public pension funds. For the sake of comparability, it seems appropriate to carry out a comparative analysis of the retirement benefits in public pension funds and private sector pension funds. The public pension funds are predominantly designed as defined benefit pension funds, while pension funds in the private sector nowadays are generally designed as defined contribution pension funds. It should be noted that defined contribution pension funds in the public sector are rare, but after the financial crisis, an increasing number of public sector employers have established defined contribution pension plans. Munnell et al. (2014) report that the number of defined contribution pension plans in the public sector of the United States has been increasing, although they still account for only a fraction of the total assets of public pension plans. However, according to the authors' projections, defined contribution pension plans in public sector in 2042 will account for almost $19 \%$ of the public sector workforce, as well as $10 \%$ of the total assets.

From the perspective of the pension fund members, the most important indicator of the retirement benefit adequacy is the replacement rate (percentage of a worker's pre-retirement income that is paid out by a pension programme upon retirement). It measures how effectively a pension system provides a retirement income to replace salary, the main source of income before retirement. Although this concept has certain shortcomings, the replacement rate is the most frequently used indicator of the retirement income adequacy. The structure of the replacement rate depends on the structure of national pension systems. In this respect, in those countries where public PAYG pension systems are dominant (Austria, Belgium, Spain, etc.), the replacement rate is determined by the demographic profile of the population, but also by the macroeconomic and public finance factors (long-term productivity growth, efficiency in contribution collection and so forth). On the other hand, in countries where there are mandatory private sector pension funds (Iceland, Denmark, etc.), the total replacement rate depends on the replacement rate from the public pension system and from the private sector. Finally, in a number of countries (United States, United Kingdom, Ireland, Canada, etc.), pension funds in the private sector are voluntary, so the total replacement rate depends on the replacement rate from the public pension system and from voluntary pension funds, if the worker is a voluntary pension fund member. 
Three factors determine retirement benefit adequacy in defined contribution pension funds: contribution rate, working career length and investment strategy. This paper focuses on the investment strategy. Defined contribution pension funds offer various investment choices to individuals, but all the investment strategies range from conservative to aggressive. Conservative strategies are oriented to riskless assets, such as government bonds and high quality corporate bonds, while aggressive strategies are oriented to risky assets, mainly stocks. The aggressive strategies have the potential to generate superior financial outcomes, since in the long run stock returns exceed bond returns. The stock allocation may be superior due to time diversification effect, i.e., the possibility that the negative returns are more than offset by the positive returns in the long run. A significant number of studies support the superiority of stock returns compared to bond returns (Jagannathan \& Kocherlakota, 1996; Campbell \& Viceira, 2002; Siegel, 2008). The conservative strategies provide lower return rates in combination with moderate variation. However, the potential of conservative strategies to generate generous retirement benefits seems to be modest.

In the last two decades, the lifecycle investment strategies have gained popularity among defined contribution pension funds members. According to Vanguard (2018), in 2017, 92\% of the pension plans managed by Vanguard offered lifecycle strategies (target-date funds). Besides, $75 \%$ of the entire membership in these pension plans followed lifecycle strategies in investing the full retirement account balance or some part of it. For the comparison sake, in 2000 every third pension plan managed by Vanguard had lifecycle strategies offered in the investment options menu. The basic idea behind the lifecycle strategies is that young members should mainly invest in stocks, since the period until retirement is relatively long, and the riskiness of the stocks in the long run decreases. On the other hand, older members should invest in bonds, because the retirement date is relatively near. Hence, lifecycle strategy follows aggressive allocation to risky assets at the beginning of the working career and then gradually shifts towards bonds as the retirement nears.

The main goal of this paper is to determine the capability of private sector defined contribution pension funds to generate retirement benefits that are equal or exceed the retirement benefits provided by the public pension funds. Since the financial theory suggests that sound investment decisions are essential tool to build retirement account balance, the investment strategy is highlighted as the key factor in achieving the generous retirement benefit. The rest of the paper is organised as follows. In the following section, the review of previous researches and the theoretical background is given. The third section gives the data and methodology description. In the fourth part, the research findings are presented. Finally, in the fifth part, concluding remarks are given. 


\section{Literature review}

Surpirsingly, the papers that deal with the comparison of retirement benefits in public defined benefit pension funds and private defined contribution pension funds are rare. In one of the most influential papers, Johnston et al. (2001) compared the savings performance of defined benefit pension funds from the public sector and defined contribution pension funds from the private sector. The defined contribution pension fund return rate simulation has been performed using Monte Carlo simulation. For the sake of simplicity, the authors assumed that the portfolio consists of large capitalization stocks and long-term investment grade corporate bonds. In the simulation process, annual returns on large cap stocks and corporate bonds over the period 1950-1999 have been used to calculate estimates of the statistical parameters (arithmetic mean, variance and covariance). Furthermore, the authors assumed that the assets' returns are normally distributed and are linearly correlated, so the joint data distribution is bivariate normal. By using Monte Carlo simulations, the authors generated 60 pairs of annual returns of stocks and bonds randomly drawn from the bivariate normal distribution, and then repeated the simulation process a thousand times. The initial allocation of $20 \%$ stocks $-80 \%$ bonds is applied to the simulated annual return pairs. Afterwards, the allocation is changed by increasing the stock allocation by $10 \%$, and simultaneosly decreasing bonds allocation by $10 \%$. The iteration is considered a success if the portfolio does not run out of money over the specified post retirement period. Johnston et al. (2001) highlight two types of risk in defined contribution pension plans: 1) lower stock allocation does not generate enough funds to cover the public system benefit cash outflow; 2) regardless of stock-bonds ratio, there is the probability of experiencing losses. The best chances of exceeding the public benefits cash stream are found for very high stock allocations.

Clark et al. (2006) compared the performances of the defined benefit pension funds and defined contribution pension funds whose members are employees of the University of North Carolina system. Unlike private sector employees, university workers have the option of choosing whether they will be insured in the state defined benefit pension plan or defined contribution plan. The authors used the annual Census data from the University of South Carolina on the basis of which they calculated the present values of retirement benefits from the defined benefit pension funds and defined contribution pension funds, assuming that employees retire at age 65 after 30 years of working career. The findings show that older employees find the defined benefit pension plans more attractive because of the relative certainty of the retirement benefits compared to the uncertainty of the defined contribution plans. On the other hand, younger employees might have a greater desire for mobility and switching employment in the future than the older employees and hence prefer the defined contribution pension plans. 
Since the investment strategy represents one of the most important factors of the retirement benefit adequacy, it is no surprise that there are many studies that have analysed the performances of different investment strategies in defined contribution pension funds. Antolin et al. (2010) conducted the analysis based on a stochastic simulation of the performance of different investment strategies. Performance is evaluated in terms of the expected retirement benefit and the risk of low benefits associated with each investment strategy. The authors concluded that none of the investment strategies dominate in all simulations, but some strategies, such as those with low stock exposure (less than 10\%) and those with extremely high stock exposure (more than 80\%), generally proved inefficient. Lifecycle strategies that maintain a constant exposure to risky assets during most of the accumulation period, switching swiftly to bonds in the last decade before retirement seem to produce adequate results. Other types of lifecycle strategies generally proved less efficient than this lifecycle strategy.

Basu and Drew (2009) investigated the adequacy of various investment strategies offered by defined contribution pension plans as default strategies in Australia. The authors showed that investment strategies with high stock exposure result in higher wealth outcomes for pension plan members. Contrary to popular belief, the probability and severity of the extremely unfavourable outcomes does not increase much with increasing fraction of portfolio in stocks. Within this framework, the unfavourable outcome is the shortage of funds to achieve the wealth accumulation target. The lifecycle strategies considered in their study are shown to reduce the variability of wealth outcomes, but at the cost of producing much lower retirement wealth than what pension plan members could potentially accumulate by keeping the initial asset allocation unchanged until retirement.

Poterba et al. (2006) examined how different asset allocation strategies over the course of a working career affect the distribution of retirement wealth and the expected wealth utility at retirement. The authors analysed a constant mix investment strategy which keeps the exposure to various assets constant over time and lifecycle strategy that vary the mix of portfolio assets as the retirement nears. The analysis simulates retirement wealth using asset returns that are drawn from the historical return distribution. The simulation results show that the expected utility of an all-stock investment strategy is greater than that from any of the more conservative strategies, at modest levels of risk aversion.

\section{Methodology}

Based on previously stated views, the following research hypothesis has been formulated:

Private sector defined contribution pension funds can generate retirement benefits guaranteed by the public defined benefit pension funds. 
In order to prove this hypothesis, a multi-period model with $\mathrm{x}$ periods is created, where $\mathrm{x}$ is the working career length (expressed as number of years). The assumed values for the private sector pension fund member's age when entering the pension fund and at the retirement are 25 years and 65 years, respectively, suggesting that the working career length is 40 years. At the end of each year of the employee's working career, for $\mathrm{t} \varepsilon[0,40]$, the retirement account balance can be calculated using the formula:

$B_{t}=\left(B_{t-1}+W_{t} *\left(1+c_{t}\right) *\left(1+r_{t}\right)\right.$.

where $\mathrm{B}_{\mathrm{t}}$ and $\mathrm{B}_{\mathrm{t}-1}$ denote the amount of assets on the retirement account at the end of the year $t$ and $t-1$, respectively, $\mathrm{W}_{\mathrm{t}}$ is the employee's salary at the end of year $\mathrm{t}$ upon which the contribution rate $c_{t}$ is applied, while $r_{t}$ is the portfolio rate of return in year t. Contribution rates are given as percentages and can have a value from zero to 100 , while the rate of return can be both positive and negative. Since salary $\mathrm{W}_{\mathrm{t}}$ increases during the course of the career, a salary scale is introduced. Salary scale reflects the fact that as the time goes by the salary increases due to the following factors: increased productivity as a result of gaining experience or acquiring new skills, taking more responsible positions in the organizational structure, increasing the cost of living due to inflation. Accordingly, it is assumed that there is a salary scale with a constant increase for each additional year of career so that,

$\mathrm{W}_{\mathrm{t}}=\mathrm{W}_{0}(1+\mathrm{s})^{\mathrm{t}-1}$.

where $\mathrm{W}_{\mathrm{t}}$ is salary in the period $\mathrm{t}, \mathrm{W}_{\mathrm{o}}$ is the initial salary at the beginning of the career, and s represents the salary increment for each year of service. In any case, the growth rate should be at least equal, and preferably higher than the long-term inflation rate over the observed period. At the retirement, the retirement account balance must be equal to

$B_{40}=\left(B_{39}+W_{0}(1+s)^{39} c_{t}\right)\left(1+r_{40}\right)$.

Factors that most affect the retirement savings process are the contribution rate and the rate of return. The rate at which contributions are paid by defined contribution pension fund members in many cases is rigid from the perspective of corrections. Choi (2015) provides a great deal of explanation for this phenomenon. On the other hand, the practice of automatic enrollment that has been introduced in the United States and the United Kingdom several years ago often involves automatically increasing the contribution rates during the working career. Also, Burke (2017) states that defined contribution pension fund members are not passive in deciding on the contribution rate, since a large percentage of the individuals does not accept the default contribution rate, makes contributions at higher rates than the default contribution rate, and periodically increases the contribution rate. With this in respect, the contribution rate increase is also included in the model. 
In order to calculate the probability that the retirement account balance at retirement can exceed the amount needed to finance retirement benefits guaranteed by the public pension system, it is necessary to measure the expected retirement benefit. Public pension systems are most often established as defined benefit pension fund or according to the"Pay as You go"model. The assumption is that it is a public defined benefit pension fund, in which the basic elements for calculating the retirement benefit are the working career length, the average salary during the working career and the corresponding accrual rate. Until the beginning of the 1990 s, it was common practice in the United States and many other developed countries that retirement benefits in public pension schemes were determined as a percentage of the final salary in the year prior to retirement, which was the most favourable solution from the employee's perspective. As a rule of thumb, the retirement benefit was defined as the amount equal to $70 \%$ of the final salary for a full 40 years working career length with an accrual rate of $1,75 \%$ for each additional year of service. However, due to the steady downward trend in the size of public pension systems in a large number of countries, retirement benefits are nowadays predominantly calculated as the percent of the average salary.

If the retirement account balance is sufficient or higher than the amount needed to finance the retirement benefit cash flow guaranteed in the public defined benefit pension fund, the savings process in the private sector defined contribution pension fund successfully creates the annuity equal (or greater) than that guaranteed in the public pension system. Otherwise, if the amount is insufficient to finance the retirement benefit cash flow guaranteed in the public defined benefit pension fund, the public pension scheme is superior to the private pension funds.

To adequately capture the uncertainty factor inherent in the retirement savings process, the results of this process in the private defined contribution pension funds are simulated using the appropriate technique. Since the values of the previously defined parameters are fixed during the working career, the element whose values will be simulated is the portfolio rate of return. One of the most commonly used return simulation approaches is the Monte Carlo simulation technique, which is based on the independence of the different assets returns, that is, there is no serial correlation between the annual returns of different assets. This approach ignores the possibility of mean reversion of stock prices or returns after the initial shock (deviation upward or downward) to the long run average level, although its presence is verified in a number of research (for example, the reversal to the mean stock price and return and the implications of this movement to pension funds was proved by Spierdijk \& Bikker, 2012, while the influence of the reversal of the average interest rate on the financial performance of the pension funds was analyzed in Melicherčik \& Ševčovič, 2012).

The simulation of stock returns or interest rates can be carried out with the assumption of a reversal to the mean value using the VAR model (vector autoregression model) or single-factor interest rate models (Vasicek model, CIR 
model and Hull-White model). Modeling presupposes the existence of the component of the theoretical average that is deterministic in nature and of the uncertainty component that is stochastic in nature, since it involves the Wiener process as a source of randomness (Kožul, 2013, 62). On the other hand, if the "random walk" assumption is introduced, according to which the stock prices after the shock do not return to the long-run average, the price changes are random and can not be predicted in any way, which is in line with the efficient market hypothesis. Based on the "random walk" assumption, two key features of the Monte Carlo return generation process can be highlighted. First, stock returns are not in autocorrelation with past returns. Second, data on the past return realization are used as the basis for the return simulation. Blake et al. (2001) and Johnston et al. (2001) were among the first to use the Monte Carlo simulation to evaluate the financial risks that pension funds face.

Monte Carlo simulation is a general method of modeling stochastic processes by using random numbers drawn from a probability distribution that is assumed to adequately represent the uncertain elements of the process being modeled (Basu, 2008, 74). Unlike historical simulation, which does not suppose a certain theoretical probability distribution, Monte Carlo evaluates statistical parameters (arithmetic mean, standard deviation or correlation coefficient) based on past data, and then evaluates the parameters with random changes to simulate future outcomes. In the most commonly used form, which is applied in further analysis, the assumption is that the stock returns and bond returns follow a normal distribution.

Within each simulation, the returns are selected randomly from the probability distribution corresponding to the historical return data for different assets. In the long run, there is evidence that the annual returns of stocks and bonds follow a normal probability distribution, although in the short term they follow the "random walk" path. The probability that the private sector pension funds will generate a financial flow equal or greater than that guaranteed by a public pension system can be significant only if a considerable fraction of portfolio is invested in stocks. Some research have shown that the stock allocation must be greater than $80 \%$ or the portfolio must be exclusively invested in stocks (Poterba et al., 2006; Antolin et al., 2010).

Simulation implies that in each iteration 40 annual returns are randomly drawn (for the working career length of 40 years) from the normal probability distribution. Each return corresponds to one year in the observed multi-period model. The dataset of simulated returns is necessary for calculating the retirement account balance at the end of period t. The simulation is repeated a thousand times, and the results at the end of the 40-year period are recorded. The number of successes, that is, the simulations in which the amount of financial assets $\mathrm{B}_{40}$ is greater than the amount of financial resources needed to finance retirement benefit 
determined according to the replacement rate of $70 \%$, is divided by the total number of simulated results giving an average probability of success.

Table 1. Parameter values for the pension fund model

\begin{tabular}{|c|c|}
\hline Parameter & Assumed value \\
\hline Inflation rate & $2 \%$ \\
\hline Wage growth rate & $2 \%$ \\
\hline $\begin{array}{c}\text { The retirement benefit accrual rate per additional year of } \\
\text { working career }\end{array}$ & $1,75 \%$ \\
\hline Replacement rate -40 years of working career & $70 \%$ \\
\hline Interest rate & $5 \%$ \\
\hline The expected retirement benefit payout period & 20 \\
\hline The value of the whole life annuity (monthly payments) & 12,627 \\
\hline
\end{tabular}

Source: Authors

A further analysis develops the previously explained model, with the introduction of the parameter values given in Table 1. Once the values of the key parameters are fixed for monitoring the dynamics of the retirement account balance, the next step involves defining the different investment strategies followed by pension fund member during his working career. Formulating an investment strategy requires distinguishing the available financial instruments. From this perspective, the most important decision is which financial instruments to include in portfolio.

The portfolio includes stocks, as risky financial instruments, and long-term bonds, as non-risky financial instruments. For the stock market returns description, the annual returns of the S\&P 500 index in the period from 1950 to 2016 are used. The annual returns of high quality corporate bonds and US government bonds with a maturity of 10 years are used to describe the long-term bond market returns. Annual returns data for the observed financial instruments are available in the electronic database of Aswath Damodaran. With the available time series of annual returns over a period of several decades, the arithmetic mean and standard deviation for the selected financial instruments can be calculated. In addition, it is also necessary to calculate the covariance between the different financial instruments returns. With these parameters defined, the mean portfolio return that includs stocks and government bonds can be calculated as the weighted average of the returns of financial instruments in the portfolio:

$\mu_{\text {portfolio }}=w_{s \& p 500} \mu_{s \& p 500}+\left(1-w_{s \& p 500}\right) \mu_{10 u s t}$,

where $\mathrm{w}_{\mathrm{s} \& \mathrm{p} 500}$ represents the fraction of portfolio invested in stocks, $\mu_{\text {s\&p500 }}$ and $\mu_{10 u s t}$ represent the average stock and 10-year government bond returns, respectively. The standard deviation of the portfolio is calculated using the formula: 
$\left.\sigma_{p}=w_{s \& p 500}^{2} \sigma_{s \& p 500}^{2}+\left(1-w_{s \& p 500}\right)^{2} \sigma_{10 u s t}^{2}+2 w_{s \& p 500}\left(1-w_{s \& p 500}\right) \operatorname{cov}(s \& p 500,10 u s t)\right)^{\frac{1}{2}}$,

where $\sigma_{\mathrm{p}}, \sigma_{\mathrm{s} \& \mathrm{p} 500}$ and $\sigma_{10 \text { ust }}$ denote the standard deviation of the total portfolio, stocks and government bonds.

As for the savings process in the private sector defined contribution pension fund, the following investment strategies are considered:

1. Extremely aggressive strategy: portfolio is invested in stocks during the entire working career;

2. Moderately aggressive strategy: portfolio consists of two types of financial instruments, stocks and high quality corporate bonds. In the first thirty years of the working career, $80 \%$ of the portfolio is invested in stocks, while the remaining $20 \%$ are invested in bonds; in the last ten years of working career, the ratio changes, so that the stocks account for $40 \%$ of the portfolio, and bonds account for $60 \%$ of the portfolio;

3. Conservative strategy: portfolio is invested in government bonds during the entire working career;

4. Lifecycle strategy: portfolio is invested in stocks during the first thirty years of working career; afterwards, the stock ratio decreases $10 \%$ annualy, simultaneosly followed with the government bond ratio annual increase. At retirement, portfolio is entirely invested in government bonds.

The assumption used in further analysis is that, in the long run, stocks and bonds returns are normally distributed, although in the short term, returns follow the random walk path. This assumption was used by Blake, Cairns, Dowd (2001), Johnston, Forbes and Hatem (2001), Byrne et al. (2006). Based on S\&P 500 index data, as the indicator of the stock market's performance, US high quality corporate bonds returns data and the US 10-year government bonds annual returns data, as indicators of fixed income market's performance, descriptive statistics are shown in Table 2.

Table 2. Stock market, high quality corporate bonds and government bonds indicators

\begin{tabular}{||c|c|c|c||}
\hline \hline & S\&P 500 & $\begin{array}{c}\text { High quality } \\
\text { corporate bonds }\end{array}$ & $\begin{array}{c}\text { 10-year government } \\
\text { bonds }\end{array}$ \\
\hline $\begin{array}{c}\text { Average rate } \\
\text { of return }\end{array}$ & $8,65 \%$ & $6,56 \%$ & $5,74 \%$ \\
\hline $\begin{array}{c}\text { Standard } \\
\text { deviation }\end{array}$ & $15,57 \%$ & $2,77 \%$ & $2,82 \%$ \\
\hline $\begin{array}{c}\text { Minimum } \\
\text { return }\end{array}$ & $-37,22 \%$ & $2,62 \%$ & $1,88 \%$ \\
\hline $\begin{array}{c}\text { Maximum } \\
\text { return }\end{array}$ & $39,83 \%$ & $14,17 \%$ & $14,59 \%$ \\
\hline
\end{tabular}

Source: Authors' calculations 
The following Table 3 shows the correlation matrix for the observed financial instruments. The absence of correlation between the movements of the S\&P 500 index, on the one hand, and high quality corporate bonds and long-term government bonds, on the other hand, is evident. Positive correlation exists between long-term government bonds and corporate bonds, which suggests that investing in both assets will not particularly improve the portfolio diversification. However, given the popularity of these financial instruments in the pension funds portfolio, both financial instruments are included in the analysis, but within different investment strategies: high quality corporate bonds are included in the moderately aggressive strategy framework, and long-term government bonds are included in conservative and lifecycle investment strategy frameworks.

Table 3: Correlation matrix for the S\&P 500, high quality corporate bonds and 10-year government bonds returns

\begin{tabular}{||c|c|c|c|}
\hline & S\&P 500 & $\begin{array}{c}\text { High quality } \\
\text { corporate bonds }\end{array}$ & $\begin{array}{c}\text { 10-year government } \\
\text { bonds }\end{array}$ \\
\hline S\&P 500 & 1 & $-0,04211$ & $-0,040536$ \\
\hline $\begin{array}{c}\text { High quality } \\
\text { corporate bonds }\end{array}$ & $-0,04211$ & 1 & 0,9678881 \\
\hline $\begin{array}{c}\mathbf{1 0}-\text { year } \\
\text { government bonds }\end{array}$ & $-0,040536$ & 0,967888 & 1 \\
\hline \hline
\end{tabular}

Source: Authors' calculations

Using the Monte Carlo simulation, a simulation of random annual returns that are normally distributed with arithmetic mean, standard deviation and correlation coefficient calculated on the basis of historical data is carried out. Given that it is a 40-year period, this means that 40-year return series will be formed for each of the three financial instruments. This method of simulation of investment returns was previosly used in Johnston, Forbes and Hatem (2001).

Since the pension fund member is interested not only in the retirement account balance at retirement, but also in the uncertainty of the realization of the expected retirement benefit, the risk of loss indicators are introduced in the analysis. In this case, the loss represents the lack of assets necessary to achieve the expected retirement benefit. To measure the loss risk, VaR (Value-at-Risk) values are used, at defined confidence levels, and the ETL (expected tail-loss) indicators, which are the average values of the losses greater than the VAR values at defined confidence levels, weighted by the probability of realization. Calculating these indicators can provide a more accurate measure of severity of adverse outcomes for each of the selected investment strategies. 


\section{Results}

The simulation process has generated the succes rates of the investment strategies at different contribution rates $(5 \%, 10 \%, 15 \%, 20 \%, 25 \%$ and $30 \%)$. From Table 4 it can be noted that the contribution rate is an important factor in achieving a satisfactory level of investment strategy performance. At the contribution rate of $5 \%$, none of the strategies achieve significant rate of success.

Table 4. The succes rate of the investment strategies at different contribution rates (the replacement rate equals $70 \%$ )

\begin{tabular}{||c|c|c|c|c||}
\hline $\begin{array}{c}\text { Contribution } \\
\text { rate }\end{array}$ & $\begin{array}{c}\text { Extremely } \\
\text { aggressive }\end{array}$ & $\begin{array}{c}\text { Moderately } \\
\text { aggressive }\end{array}$ & $\begin{array}{c}\text { Conservative } \\
\text { strategy }\end{array}$ & $\begin{array}{c}\text { Lifecycle } \\
\text { strategy }\end{array}$ \\
\hline $\mathbf{5 \%}$ & $14,2 \%$ & $4,8 \%$ & $0 \%$ & $10,1 \%$ \\
\hline $\mathbf{1 0} \%$ & $50,0 \%$ & $42,9 \%$ & $0 \%$ & $44,8 \%$ \\
\hline $\mathbf{1 5 \%}$ & $74,1 \%$ & $81,2 \%$ & 36,3 & $74,5 \%$ \\
\hline $\mathbf{2 0} \%$ & 87,9 & $95,2 \%$ & 98,6 & $89,6 \%$ \\
\hline $\mathbf{2 5} \%$ & 93,5 & 99,3 & $99,9 \%$ & $96,8 \%$ \\
\hline $\mathbf{3 0} \%$ & $96,6 \%$ & $99,9 \%$ & $100 \%$ & $98,2 \%$ \\
\hline
\end{tabular}

Source: Authors' calculations

Moreover, conservative strategy achieves a success rate of $0 \%$, which means that no simulated result is sufficient to finance the retirement cash flow equal to $70 \%$ of the final salary. The aggressive strategy and lifecycle strategy are the only strategies that achieve a succes rate higher than $10 \%$, which is an unfavourable result from the member's perspective.

At the contribution rate equal to $10 \%$, the situation is slightly more favourable. The conservative strategy still has a success rate equal to $0 \%$. However, the extremely aggressive strategy has a success rate of $50 \%$, while lifecycle strategy has a success rate of approximately $45 \%$. In other words, the extremely aggressive strategy and lifecycle strategy in approximately 500 of 1000 simulations generate retirement benefits that are equal or exceed retirement benefits within the public pension system. At the contribution rate of $15 \%$, the success rate of all strategies has improved significantly. All investment strategies, except for conservative strategy, achieve a success rate of over $70 \%$, and the most successful moderately aggressive strategy has a success rate of approximately $81 \%$. It can be said that the contribution rate of $15 \%$ represents a turning point, because from this level the rate of success increases significantly for all strategies. At higher contribution rates, all strategies have a significant success rate of around $90 \%$. At the contribution rate of $20 \%$, even the conservative strategy has a high success rate of around $98 \%$, while the extremely aggressive and lifecycle strategy have success rates that are slightly below $90 \%$ ( $88 \%$ and $89 \%$, respectively). 
It can be concluded that, at low contribution rates of $5 \%$ and $10 \%$, the success rates of the selected investment strategies in generating financial results that are more favourable than those generated by the public pension system are low. At the contribution rate of $15 \%$, the results are significantly more favourable, while at the contribution rate of $20 \%$ and higher, there is a significant degree of certainty regarding the effectiveness of strategies.

This result at first glance is encouraging. However, it should be kept in mind that the contribution rates in defined contribution pension funds in many countries, especially in those countries where defined contribution pension funds are voluntary, are relatively low. For example, according to the Office for National Statistics (2017), the average contribution rate in private defined contribution pension funds in the UK is only $3,4 \%$, as a sum of the employee contribution rate and the employer contribution rate. In addition, it is also worrying that the contribution rates in private defined contribution pension funds have fallen since 2013 , when they amounted to about $9 \%$. With such low contribution rates, it is impossible to expect that defined contribution pension funds generate adequate levels of retirement savings.

On the other hand, the generosity of public pension systems is gradually decreasing in most countries. One of the means of reducing the generosity is to change the basis for calculating the retirement benefit in the benefit formula, that is, the introduction of the average salary instead of the final salary. Consequently, the simulations were carried out for this scenario, with the accrual rate for each additional year of career unchanged and amounting to $1,75 \%$, so that an individual who spent the entire working career in the public sector in the defined benefit pension fund can make a retirement benefit pension equal to $70 \%$ of the average salary. The rates of success of investment strategies in the defined contribution pension funds in achieving this amount of retirement benefit are given in Table 5.

Table 5. The success rate of investment strategies, at different contribution rates (the retirement benefit is equal to $70 \%$ of the average salary)

\begin{tabular}{||c|c|c|c|c||}
\hline \hline $\begin{array}{c}\text { Contribution } \\
\text { rate }\end{array}$ & $\begin{array}{c}\text { Extremely } \\
\text { aggresive }\end{array}$ & $\begin{array}{c}\text { Moderately } \\
\text { aggressive }\end{array}$ & Conservative & Lifecycle \\
\hline $5 \%$ & $51,8 \%$ & $46,3 \%$ & $0 \%$ & $48,3 \%$ \\
\hline $10 \%$ & $84,9 \%$ & $95,9 \%$ & $99,2 \%$ & $89,8 \%$ \\
\hline $15 \%$ & $96,6 \%$ & $99,8 \%$ & $100 \%$ & $98,1 \%$ \\
\hline $20 \%$ & $99 \%$ & $100 \%$ & $100 \%$ & $99,8 \%$ \\
\hline $25 \%$ & $99,5 \%$ & $100 \%$ & $100 \%$ & $99,8 \%$ \\
\hline $30 \%$ & $99,8 \%$ & $100 \%$ & $100 \%$ & $100 \%$ \\
\hline
\end{tabular}

Source: Authors'calculations 
At first glance, it can be noted that the goal is achievable even at low contribution rates $(5 \%$ and $10 \%)$. With a contribution rate of $10 \%$, each of the investment strategies achieves a success rate of approximately $90 \%$, which can be considered a satisfactory result. At higher contribution rates, it can be said that the certainty exists regarding the accumulation of enough funds to finance the expected retirement benefit.

After looking at the success rates for selected investment strategies, in the continuation of reviewing the results of the analysis, the main indicators of the financial results for each of the investment strategies are given. Table 6 shows the simulation results for all the observed investment strategies. A conservative strategy is characterised by low coefficient of variation of approximately $10 \%$, for all the contribution rates, suggesting that the simulated results have a small dispersion. The average financial result for the conservative strategy is approximately 990 thousand monetary units (at 15\% contribution rate), while the median value is roughly the same as average. For the extremely aggressive strategy, the average value is about 1,9 million, and for the moderately aggressive strategy about 1,6 million monetary units. On the other hand, the coefficient of variation is considerably higher than in the case of the conservative strategy and ranges from $68 \%$ to $86 \%$ for the extremely aggressive strategy, while for the moderately aggressive strategy is approximately $44 \%$. The average financial result for the lifecycle strategy is approximately 1,75 million monetary units, while the coefficient of variation ranges from $59 \%$ to $64 \%$.

Table 6. Simulation results for the conservative, extremely aggressive, moderately aggressive and lifecycle strategy, at different contribution rates

\begin{tabular}{|c|c|c|c|c|c|c||}
\hline & \multicolumn{7}{|c|}{ Contribution rate } \\
\hline & $\mathbf{5 \%}$ & $\mathbf{1 0 \%}$ & $\mathbf{1 5 \%}$ & $\mathbf{2 0 \%}$ & $\mathbf{2 5 \%}$ & $\mathbf{3 0 \%}$ \\
\hline \multicolumn{7}{|c|}{ Conservative strategy } \\
\hline Minimum value & 219439 & 453820 & 694118 & 929531 & 1188092 & 1427461 \\
\hline Maximum value & 460955 & 885693 & 1487675 & 1842240 & 2310888 & 2824300 \\
\hline Average value & 329740 & 665942 & 988480 & 1314099 & 1654089 & 1994724 \\
\hline Median value & 328609 & 663488 & 978358 & 1310966 & 1643875 & 1979943 \\
\hline Standard deviation & 35404 & 70475 & 107475 & 140219 & 178800 & 221402 \\
\hline Coef. of variation & $10,74 \%$ & $10,58 \%$ & $10,87 \%$ & $10,67 \%$ & $10,81 \%$ & $11,10 \%$ \\
\hline \multicolumn{7}{|c|}{ Extremely aggresive strategy } \\
\hline Minimum value & 67346 & 173934 & 234682 & 387579 & 418295 & 498251 \\
\hline Maximum value & 5257516 & 6793905 & 14703326 & 12313465 & 36636824 & 24911299 \\
\hline Average value & 631831 & 1249965 & 1916454 & 2527463 & 3299164 & 3804919 \\
\hline Median value & 500532 & 1018691 & 1534352 & 2090931 & 2592134 & 3025515 \\
\hline Standard deviation & 457271 & 854768 & 1424273 & 1729691 & 2861251 & 2807512 \\
\hline Coef. of variation & $72,37 \%$ & $68,38 \%$ & $74,32 \%$ & $68,44 \%$ & $86,73 \%$ & $73,79 \%$ \\
\hline \hline
\end{tabular}




\begin{tabular}{|c|c|c|c|c|c|c||}
\hline \multicolumn{7}{|c|}{ Moderately aggressive strategy } \\
\hline Minimum value & 179002 & 310079 & 490983 & 572296 & 794333 & 1035890 \\
\hline Maximum value & 2781482 & 3948353 & 5439990 & 7932293 & 10325653 & 10567806 \\
\hline Average value & 546979 & 1043205 & 1603661 & 2128615 & 2713214 & 3217606 \\
\hline Median value & 506107 & 946277 & 1440699 & 1930032 & 2449155 & 2916496 \\
\hline Standard deviation & 235962 & 444358 & 717462 & 920888 & 1197993 & 1419840 \\
\hline Coef. of variation & $43,14 \%$ & $42,60 \%$ & $44,74 \%$ & $43,26 \%$ & $44,15 \%$ & $44,13 \%$ \\
\hline \multicolumn{7}{|c|}{ Lifecycle strategy } \\
\hline Minimum value & 106995 & 233986 & 314248 & 389480 & 518708 & 699687 \\
\hline Maximum value & 2929254 & 5096773 & 8638307 & 12343121 & 18784492 & 21970812 \\
\hline Average value & 585140 & 1157055 & 1753377 & 2299160 & 3083966 & 3505749 \\
\hline Median value & 489469 & 949860 & 1495300 & 1936110 & 2591284 & 3005007 \\
\hline Standard deviation & 359551 & 716588 & 1098013 & 1362949 & 1994020 & 2170406 \\
\hline Coef. of variation & $61,45 \%$ & $61,93 \%$ & $62,62 \%$ & $59,28 \%$ & $64,66 \%$ & $61,91 \%$ \\
\hline
\end{tabular}

Source: Authors' calculations

Table 7 summarises the rates of success and average financial results for all investment strategies at different contribution rates. Viewed from this perspective, the extremely aggressive strategy is the only strategy that generates success rate of approximately $50 \%$, at the contribution rate of $10 \%$, while the success rates of the remaining strategies are significantly lower. At the contribution rate of $15 \%$, all strategies, except for the conservative strategy, achieve satisfactory success rates higher than $70 \%$. At higher contribution rates all the investment strategies achieve exceptional success rates that exceed the level of $85 \%$.

Table 7. The success rate and the average financial result of the investment strategies, at different contribution rates

\begin{tabular}{|c|c|c|c|c|c|c||}
\hline \hline & \multicolumn{7}{|c|}{ Contribution rate } \\
\cline { 2 - 7 } & $\mathbf{5 \%}$ & $\mathbf{1 0 \%}$ & $\mathbf{1 5 \%}$ & $\mathbf{2 0 \%}$ & $\mathbf{2 5 \%}$ & $\mathbf{3 0 \%}$ \\
\hline Conservative & $0,00 \%$ & $0,00 \%$ & $36,30 \%$ & $98,60 \%$ & $99,90 \%$ & $100,00 \%$ \\
\hline $\begin{array}{c}\text { Extremely } \\
\text { aggressive }\end{array}$ & $14,20 \%$ & $50,00 \%$ & $74,10 \%$ & $87,90 \%$ & $93,50 \%$ & $96,60 \%$ \\
\hline $\begin{array}{c}\text { Moderately } \\
\text { agressive }\end{array}$ & $4,80 \%$ & $42,90 \%$ & $81,20 \%$ & $95,20 \%$ & $99,30 \%$ & $99,90 \%$ \\
\hline Lifecycle & $10,10 \%$ & $44,80 \%$ & $74,50 \%$ & $89,60 \%$ & $96,80 \%$ & $98,20 \%$ \\
\hline $\begin{array}{c}\text { Conservative } \\
\text { Extremely } \\
\text { agressive }\end{array}$ & 329740 & 665942 & 988480 & 1314099 & 1654089 & 1994724 \\
\hline $\begin{array}{c}\text { Moderately } \\
\text { agressive }\end{array}$ & 531831 & 1249965 & 1916454 & 2527463 & 3299164 & 3804919 \\
\hline Lifecycle & 585140 & 1157055 & 1753377 & 2299160 & 3083966 & 3505749 \\
\hline
\end{tabular}


On the other hand, in addition to the success rate, it is necessary to look at the risk of unfavourable outcomes. In this respect, Table 8 summarises VaR and ETL values for all investment strategies at confidence levels of $90 \%, 95 \%$ and $99 \%$, respectively, and the contribution rate of $10 \%$. VaR values are the highest for the aggressive strategies, followed by the lifecycle strategy and the conservative strategy. This is also the case regarding ETL values.

Table 8. VaR indicators and ETL indicators, contribution rate $10 \%$, replacement rate $70 \%$

\begin{tabular}{||c|c|c|c|c|c|c||}
\hline & \multicolumn{3}{|c|}{ VaR (Value at Risk) } & \multicolumn{3}{c||}{ ETL (expected tail loss) } \\
\cline { 2 - 7 } & $\mathbf{9 0 \%}$ & $\mathbf{9 5 \%}$ & $\mathbf{9 9 \%}$ & $\mathbf{9 0 \%}$ & $\mathbf{9 5 \%}$ & $\mathbf{9 9 \%}$ \\
\hline Conservative & 439158 & 468071 & 515660 & 472359 & 491314 & 530336 \\
\hline $\begin{array}{c}\text { Extremely } \\
\text { aggressive }\end{array}$ & 572187 & 645213 & 745554 & 656726 & 703427 & 786557 \\
\hline $\begin{array}{c}\text { Moderately } \\
\text { aggressive }\end{array}$ & 438928 & 489432 & 579041 & 502508 & 544295 & 620489 \\
\hline $\begin{array}{c}\text { Lifecycle } \\
\text { strategy }\end{array}$ & 524093 & 611484 & 683338 & 612433 & 655147 & 712425 \\
\hline
\end{tabular}

Source: Authors' calculations

The extremely aggressive strategy generates the most extreme results, that is, the biggest losses with the assumed confidence levels, followed by the lifecycle strategy. ETL values confirm this conclusion. Differences in VaR values are not negligible. At the confidence level of $95 \%$, the difference in VaR values for the extremely aggressive and conservative strategy amounts to approximately 177 thousand monetary units, while the difference in ETL values at that confidence level is approximately 256 thousand monetary units. Thus, the extremely aggressive strategy that has the highest success rate of all investment strategies at lower contribution rates ( $5 \%$ and $10 \%$ ), as well as the highest average and median financial result for all selected contribution rates, has the most extreme adverse outcomes. Lifecycle strategy has lower VaR values compared to the extremely aggressive strategy, but this reduction comes at the expense of reducing the average financial result.

If pension fund member pays contributions at $10 \%$ rate or lower, the strategies that generate a certain level of probability of achieving the adequate level of retirement savings are extremely aggressive strategy, moderately aggressive strategy and lifecycle strategy. Conservative strategy does not have the built-in capacity to reach target accumulation due to over-reliance on fixed-income financial instruments. On the other hand, the situation is interesting if the contributions are paid at the rate of $15 \%$ throughout the entire working career. In this situation, the success rate is relatively similar for all strategies (except for the 
conservative strategy), ranging from $71,2 \%$ to $81,2 \%$. As for VaR and ETL values, the extremely aggressive strategy registers the highest values for all confidence levels, followed by lifecycle strategy (Table 9). VaR values for moderately aggressive strategy are lower than for the extremely aggressive strategy, and the difference is significant. For example, the difference between VaR $(95 \%)$ for moderately aggressive and extremely aggressive strategy amounts to approximately 195,000 monetary units, and if VaR $(99 \%)$ is considered, the difference is as much as 230,000 monetary units.

Differences in the VAR and ETL values are even greater if we compare conservative strategy with the extremely aggressive and lifecycle strategy. Since the rate of success is roughly equal regardless of which strategy is being chosen, $\mathrm{VaR}$ values can serve as a benchmark in the process of selecting an adequate strategy. The pension fund member should choose the strategy whose potential for the realization of extremely unfavourable outcomes is the lowest. In this respect, conservative strategy with high exposure to government bonds and the moderately aggressive strategy may be favourable solutions to pension fund members. By following these strategies, the pension fund members can achieve acceptable success rates in achieving the retirement benefit guaranteed in the public pension system of approximately $75 \%$, along with the reduction of probability of reporting extremely unfavourable outcomes. This is not the case with the strategies with high exposure to stocks (extremely aggressive and lifecycle strategies).

Table 9. VaR and ETL values, at the contribution rate of $15 \%$ (the replacement rate equals $\mathbf{7 0 \%}$ )

\begin{tabular}{|c|c|c|c|c|c|c||}
\hline \multirow{2}{*}{} & \multicolumn{3}{|c|}{ VaR (Value at Risk) } & \multicolumn{3}{c|}{ ETL (expected tail loss) } \\
\cline { 2 - 7 } & $\mathbf{9 0 \%}$ & $\mathbf{9 5 \%}$ & $\mathbf{9 9 \%}$ & $\mathbf{9 0 \%}$ & $\mathbf{9 5 \%}$ & $\mathbf{9 9 \%}$ \\
\hline Conservative & 153728 & 193444 & 253209 & 201012 & 228165 & 280035 \\
\hline $\begin{array}{c}\text { Extremely } \\
\text { aggressive }\end{array}$ & 297670 & 423869 & 625817 & 450979 & 546452 & 677131 \\
\hline $\begin{array}{c}\text { Moderately } \\
\text { aggressive }\end{array}$ & 134680 & 228741 & 393175 & 254283 & 329743 & 449136 \\
\hline Lifecycle & 277940 & 423730 & 593917 & 429151 & 513595 & 638675 \\
\hline
\end{tabular}

Source: Authors'calculations

With an increase in the contribution rate to $20 \%$ and higher, all investment strategies (including the conservative) have an excellent average succes rate of approximately $88 \%$. In such a situation, given the significant certainty in the realization of the retirement benefit target, members can additionally protect themselves from the realization of extremely unfavourable outcomes, by choosing some of the less risky investment strategies. The simulation results, in this case, show that the success rate of the conservative strategy is higher than the success 
rate of the extremely aggressive strategy and lifecycle strategy, which additionally favors the choice of this investment strategy.

\section{Conclusion}

The basic question discussed in this paper is whether private sector defined contribution pension funds can generate the retirement benefit guaranteed by public sector defined benefit pension funds. The conducted empirical analysis compared the simulated retirement account balance at retirement and the amount of assets needed to finance the retirement benefit generated in the public sector. The analysis has been carried out for four investment strategies: one conservative, two aggressive and one lifecycle strategy, and the retirement benefit target is defined as $70 \%$ of the final salary. The results of the analysis show that, at low contribution rates, the probability of reaching the target is extremely small, but with the increase in the contribution rate to a level of $15 \%$, a significant increase in the success rate of all observed strategies is achieved, with the exception of the conservative strategy. However, at higher contribution rates, all investment strategies have high success rates, that is, they have the capacity to generate the retirement benefit guaranteed by the public pension funds. It is important to point out that at the contribution rate of $15 \%$ and higher, the conservative strategy has the success rate that is approximately equal to the success rates of aggressive strategies and lifecycle strategy. On the other hand, the severity of extremely unfavourable outcomes is higher for aggressive strategies and lifecycle strategy, suggesting that the conservative strategy is recommended at higher contribution rates. By following conservative strategy, pension fund members can achieve a very high success rate, but at the same time significantly reduce the likelihood of extremely unfavourable financial results. The above results of the empirical analysis confirm the research hypothesis.

\section{References}

Antolin, P., Payet, S., Yermo, J., (2010), Assessing Default Investment Strategies in Defined Contribution Pension Plans, OECD Journal: Financial Market Trends, Vol. 2010, Iss. 1, OECD Publishing

Basu, A., (2008), Essays on Asset Allocation Strategies for Defined Contribution Plans, $\mathrm{PhD}$ Thesis, The School of Economics and Finance, Queensland University of Technology Brisbane, Australia

Basu, A., Drew, M., (2009), The Appropriateness of Default Investment Options in Defined Contribution Plans: Australian Evidence, Discussion Paper, No. 2009-03, Griffith Business School

Blake, D., Cairns, A., Dowd, K., (2001), Pensionmetrics: stochastic pension plan design and value-at-risk during the accumulation phase, Insurance: Mathematics and Economics, Vol. 29, pp. 187-215 
Burke, J., Hung, A., Luoto, J., (2017), Opting out of Retirement Plan Default Settings, Working Paper, No. 1162, RAND Labor \& Population, RAND Corporation

Byrne, A., Blake, D., Cairns, A., Dowd, K., (2006), An Analysis of Default Funds in UK Defined Contribution Pension Plans, CRIS Discussion Paper Series, No 2006/VIII, Centre for Risk \& Insurance Studies, The University of Nottingham

Campbell, J., Viceira, L., (2002), Strategic Asset Allocation: Portfolio Choice for LongTerm Investors, Oxford University Press

Choi, J., (2015), Contributions to Defined Contribution Pension Plans, NBER Working Paper, No. 21467, National Bureau of Economic Research

Clark, R., Ghent, L., McDermed, A., (2006), Pension Plan Choice among University Faculty, Southern Economic Journal, Vol. 72, No. 3, pp. 560-577

Jagannnathan, R., Kocherlakota, N., (1996), Why Should Older People Invest Less in Stocks Than Younger People?, Quarterly Review, Vol. 20, No. 3, Federal Reserve Bank of Minneapolis

Johnston, K., Forbes, S., Hatem, J., (2001), A comparison of state university defined benefit and defined contribution pension plans: a Monte Carlo simulation, Financial Service Review, Vol. 10, pp. 37-44

Kožul, N., (2013), Pregled jednofaktorskih modela kamatnih stopa sa fokusom na model Hal i Vajt, Bankarstvo, Br. 3, pp. $60-69$

Melicherčik, I., Ševčovič, D., (2012), Dynamic model of pension savings management with stochastic interest rates and stock returns, y Perna, C., Sibillo, M., (eds.), Mathematical and Statistical Methods for Actuarial Sciences and Finance, Springer, pp. $295-304$

Munnell, A., Aubry, J.P., Cafarelli, M., (2014), Defined Contribution Plans in the Public Sector: An Update, State and Local Pension Plans, No. 37, Center for Retirement Research at Boston College

Office for National Statistics United Kingdom, (2017), Occupational Pension Schemes Survey-2017, Statistical Bulletin

Poterba, J., Rauh, J., Venti, S., Wise, D., (2006), Lifecycle Asset Allocation Strategies and the Distribution of 401(k) Retirement Wealth, NBER Working Paper Series, No. 11974, National Bureau of Economic Research

Siegel, J., (2008), Stocks for the Long Run $-4^{\text {th }}$ Edition, McGraw-Hill

Spierdijk, L., Bikker, J., (2012), Mean Reversion in Stock Prices: Implications for LongTerm Investors, DNB Working Paper, No. 343, De Nederlandsche Bank NV

Vanguard, (2018), How America Saves 2018 - Vanguard 2017 defined contribution plan data, Vanguard 


\section{KOMPARATIVNA ANALIZA NIVOA PENZIJSKIH NAKNADA U PRIVATNIM PENZIJSKIM FONDOVIMA I JAVNIM PENZIJSKIM SISTEMIMA}

Apstrakt: Primarni motiv za sprovođenje istraživanja predstavlja utvrđivanje uslova u kojima privatni penzijski fondovi mogu da ostvare superiornije investicione performanse $\mathrm{u}$ poređenju sa javnim penzijskim sistemima. Osnovni ciljevi istraživanja su utvrđivanje verovatnoce uspeha odabranih investicionih strategija $\mathrm{u}$ postizanju stope zamene koja je garantovana $u$ javnom penzijskom sistemu, kao i veličine potencijalnih ekstremno nepovoljnih ishoda. Metodologija korišćena u radu uključuje komparativnu analizu simuliranih finansijskih rezultata četiri investicione strategije primenjene na modelu privatnog penzijskog fonda sa definisanim doprinosima, $\mathrm{s}$ jedne strane, i penzijskih naknada koje isplaćuju penzijski fondovi sa definisanim naknadama u javnom penzijskom sistemu. Za simulaciju finansijskih rezultata $\mathrm{u}$ trenutku penzionisanja korišćena je Monte Carlo tehnika. Autori su utvrdili da je stopa uspešnosti privatnog penzijskog fonda u postizanju superiornijih finansijskih rezultata $u$ poređenju sa javnim penzijskim sistemom visoka, ali samo za stope doprinosa veće od $10 \%$. Na niskim nivoima stopa doprinosa, izuzetno agresivna strategija je jedina koja generiše umerenu stopu uspeha. Takođe, verovatnoća realizacije ekstremno nepovoljnih finansijskih rezultata najniža je za konzervativnu strategiju, što sugeriše da je za relativno visoke stope doprinosa najprikladnija opcija za učesnike u penzijskom fondu.

Ključne reči: penzijski fondovi, javni penzijski sistem, penzijske naknade, investicione strategije, Monte Karlo simulacija

\section{Authors' biographies}

Stevan Luković is a research assistant at Faculty of Economics, University of Kragujevac, Serbia. He has been employed at the Faculty of Economics since 2008. The main areas of his research and interests are pension insurance and pension funds.

Srđan Marinković is a Full Professor at Faculty of Economics, University of Niš, Serbia. He has been employed at the Faculty of Economics since 1995. His main fields of research interests are finance, financial markets and banking. He teaches courses at the Undergraduate level - Bank management and Financial markets, and the Master level - Microstructure of financial markets. 